\title{
Top-down reconstruction and the failure to "build back better" resilient communities after disaster: lessons from the 2009 L'Aquila Italy earthquake
}

\author{
Angelo Jonas Imperiale and Frank Vanclay \\ Department of Cultural Geography, University of Groningen, Groningen, Netherlands
}

Failures to

build back

better in

reconstruction

Received 6 November 2019

Revised 1 February 2020

23 March 2020

Accepted 11 April 2020

\begin{abstract}
Purpose - We consider what happened in the initial reconstruction interventions following the 6 April 2009 earthquake in L'Aquila (Italy). Using the disaster risk reduction and resilience paradigm, we discuss the cognitive and interactional failures of top-down approaches, and we analyse the main constraints to enacting inclusive social learning and socially-sustainable transformation and building back better more resilient communities in post-disaster reconstruction.

Design/methodology/approach - Our evidence comes from participant observation, action anthropology and analytic auto-ethnography conducted during the reconstruction phase following the L'Aquila earthquake. Findings were triangulated with document analysis, media analysis and retrospective interviewing conducted in 2013 and 2017.

Findings - The shift from civil defence to civil protection did not bring any advance in disaster management and development practice in terms of DRR and resilience. The militaristic command-and-control approach, which is still in vogue among civil protection systems, means that local political leaders become the civil protection authorities in a disaster area. As in the L'Aquila case, this exacerbates local social and environmental risks and impacts, inhibits local communities from learning and restricts them from participating in post-disaster interventions.

Originality/value - Most previous commentary on disaster recovery and reconstruction following the L'Aquila earthquake has focussed on the top-down approach carried out by the national government and the Italian Department of Civil Protection (DCP). This paper is unique in that it sheds light on how the commandand-control approach was also implemented by local authority figures and on how this undermined building back better more resilient communities.
\end{abstract}

Keywords Disaster risk reduction, Resilience, Command and control, Reconstruction, Earthquakes, Disaster management

Paper type Research paper

\section{Introduction}

The reconstruction phase in the disaster management cycle includes the management of and processes related to the restoration of damaged buildings and construction of replacement permanent housing (i.e. resettlement) and the social dimensions of these activities (Quarantelli, 1998; Chang et al., 2010; Oliver-Smith et al., 2017; Sadiqi et al., 2017).

(C) Angelo Jonas Imperiale and Frank Vanclay. Published by Emerald Publishing Limited. This article is published under the Creative Commons Attribution (CC BY 4.0) licence. Anyone may reproduce, distribute, translate and create derivative works of this article (for both commercial \& non-commercial purposes), subject to full attribution to the original publication and authors. The full terms of this licence may be seen at http://creativecommons.org/licences/by/4.0/legalcode.

The authors thank Professor Franco La Cecla, Professor Christian Hanus, Professor Roberto PirzioBiroli, Dr Sara Gutarra, Dr Andri Gurtmann, and the local project team and all the inhabitants who took part in reconstruction project proposals.

This paper forms part of a special section "Resilience and post-disaster recovery: a critical reassessment of anticipatory strategies, 'build back better' and capacity building" guest edited by Annabelle Moatty.

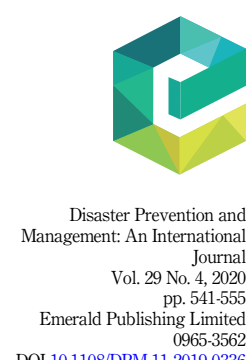

DOI 10.1108/DPM-11-2019-0336 
DPM

29,4

542

In addition to local communities, there are many other actors, local and external, involved in reconstruction, including disaster management agencies, governments at all levels, housing organisations, building firms, NGOs, private investors, universities and research foundations and local and national professionals. All disaster management interventions, including reconstruction, have five components: (1) an institutional strategy; (2) financial strategy; (3) community participation approach; (4) physical planning (e.g. disaster rubble management and local infrastructure reconstruction) and (5) risk management (Jha et al., 2010). Decisions made and actions carried out regarding these components will have positive and negative impacts on local communities and will reduce or exacerbate vulnerabilities and social risks (e.g. inequity, social exclusion and elite capture), as well as mitigate or worsen the social impacts of disasters (Imperiale and Vanclay, 2019a, 2020; Finucane et al., 2020).

The housing sector tends to experience major losses from disasters, especially earthquakes (Amin and Goldestein, 2008). Reconstruction is a key activity in any postdisaster situation (UNDRO, 1982; Jha et al., 2010). Community marginalisation from reconstruction exacerbates local vulnerabilities and associated disaster risks and impacts (Sadiqi et al., 2017). Since the 1980s, various United Nations documents have promulgated a DRR and resilience paradigm that should be the basis of disaster and development agencies in all countries (UNDRO, 1982; INDNR, 1994; UNISDR, 2005, 2015). The DRR and resilience paradigm advocates reducing vulnerabilities and risks, enacting genuine community engagement and empowerment and building local community resilience at all phases of disaster management and development (IFRC and RCS, 2004; UNISDR, 2007; Benson and Twigg, 2007; UNISDR and UNDP, 2007; Jha et al., 2010).

Resilience has many definitions and a long history across several disciplines (Adger, 2000; Berkes et al., 2003; Folke, 2006; Norris et al., 2008; Folke et al., 2010; Davidson, 2010; Berkes and Ross, 2013, 2016). Strengthening the resilience of communities before and after disasters was first advocated by the United Nations in the Yokohama Strategy (IDNDR, 1994). The Hyogo Framework for Action 2005 emphasised the need for proactive measures and argued that the response, recovery and reconstruction phases are windows of opportunity to build back better livelihoods and physical and socio-economic structures in ways that will build community resilience and reduce vulnerability to future disaster risks (UNISDR, 2005).

In a previous work (Imperiale and Vanclay, 2016a), we defined local community resilience as the agency (i.e. a set of cognitive and interactional capacities and processes) that enables members of local communities to collectively learn from crises, disasters and other unwanted changes and positively transform towards reducing local vulnerabilities, social risks and associated disaster risks and impacts, thus enhancing the well-being of all members of a community, especially the most vulnerable. To build back better more resilient and sustainable landscapes and communities, understanding, recognising, engaging and empowering the capacities of local people to collectively learn and transform towards reducing vulnerabilities and enhancing DRR and community well-being is crucial (Imperiale and Vanclay, 2016b).

Too often, disaster management interventions become structural failures that ignore, exclude or weaken community resilience through "counterproductive help", i.e. increased dependency on external support (Illich, 1976, 1978; Ellerman, 2006), thus failing to build resilience at the cognitive (i.e. counterproductive learning) and interactional levels (i.e. counterproductive transformation). We define counterproductive learning, in the context of disasters, as failures at the cognitive level induced by counterproductive help that inhibits people from learning from local vulnerabilities, the root causes of disasters and disaster risks and impacts. Counterproductive learning worsens local social risks, including rent-seeking, elite capture, organised crime infiltration and corruption. Counterproductive transformations 
result in worsening local inequities, social exclusion and a lack of capacity, thereby exacerbating local vulnerabilities and associated disaster risks and impacts. Unfortunately, before and after disasters, business-as-usual and uncertainty about how resilience can be strengthened at the local community level enable traditional top-down models of planning and management to be perpetuated and international principles to be ignored (Imperiale and Vanclay, 2019a, b, 2020).

Previously, we conceptualised the mechanism that states with centralised, top-down civil protection systems enact in times of crises and disasters, thus creating counterproductive learning and facilitating disaster capitalism (Imperiale and Vanclay, 2020). In this paper, using the DRR and resilience paradigm, we analyse the top-down approach to post-disaster reconstruction that was applied by the national civil protection agency and the local authority figures after the 2009 earthquake in L'Aquila, Italy. We reflect on the top-down reconstruction interventions that were implemented, and how such an approach represents a component of the mechanism that creates counterproductive learning and facilitates disaster capitalism, thus failing to build back better resilient communities.

\section{The 6 April 2009 earthquake, red zones and the crater}

On 6 April 2009, a 6.3 Mw earthquake devastated the regional capital, L'Aquila and 56 surrounding municipalities. Some 309 persons were killed, 1,500 injured and 70,000 people were rendered homeless in the affected area, which became known as "the crater". Within hours, a state of emergency was declared and remained in force for three years, an extraordinarily long period (Venice Commission, 1995; Khakee, 2009). Exclusion areas (i.e. red zones) were established to restrict local people from the severely-affected town centres across the crater. To coordinate the emergency, the national Department of Civil Protection (DCP) established a Directorate of Command and Control (DICOMAC). The powers of local authority figures - including the President of the Abruzzo Region, the President of the L'Aquila Province and the mayors of the local municipalities - were expanded, while local councils were suspended. Providing that they deferred to the DCP, the local authority figures were granted emergency powers and expected to implement key disaster management activities, including safety measure implementation, disaster rubble management and reconstruction interventions.

The recovery process has been severely criticised, including by a European Parliament enquiry concerned about the misuse of the $€ 493$ million it provided (Søndergaard, 2013). There was organised crime infiltration (Galullo, 2009; Postiglione, 2010; Libera, 2010; Søndergaard, 2013; DNA, 2017; Bindi, 2018). Since the earthquake, many legal actions have been taken relating to allegations of fraud, corruption, bribery, inadequate public administration and Mafia infiltration, implicating national and local public officers and building firms (Imperiale and Vanclay, 2019a, b, 2020). Most academic research about the recovery process has primarily focused on how the Italian government and the DCP carried out disaster recovery. There has been little research on the actions local authority figures took, the emergency powers they were given, how their actions were implemented or the negative consequences created.

While the government was militarising the area and the DCP was managing the tent camps, implementing temporary housing solutions and conducting the "habitability" assessments (see below), the ordinance issued by Prime Minister Silvio Berlusconi (OPCM n.3753, 6 April 2009) entitled the Presidents of the Abruzzo Region and the L'Aquila province, and the local mayors to, among other things: (1) establish technical teams to identify the buildings that needed safety measures (i.e. shoring-up solutions and demolitions); (2) implement safety measures; (3) manage disaster rubble and (4) design and implement reconstruction policies and interventions including tasks the local authority figures were
Failures to build back better in reconstruction 
DPM

29,4

544 responsible for in the normal situation (e.g. the building of a bridge, the enhancement of local roads and the railway, see Imperiale and Vanclay, 2020).

We consider how these actions were done and the consequences of this, and we discuss how local and national authority figures failed to build back better more sustainable and resilient communities. We specifically consider the extent to which the exclusion of local communities was evident in how the top-down planning approach was implemented, and how this led to counterproductive learning and to building a culture of disaster capitalism rather than to community well-being and resilience. More than 10 years after the earthquake, the red zones are still officially in force, and many buildings remain crammed with temporary shoring-up solutions and are overgrown and deteriorating. There are also many empty apartments now owned by the local municipalities because the original owners decided to move away and surrendered ownership. This is an increasing burden on these municipalities. Nevertheless, some 10,000 people still live in temporary accommodation.

\section{Methodology}

The primary author is an Italian citizen who was a resident in the L'Aquila region for most of his life. He was present in L'Aquila city on the night of the earthquake and lived in the L'Aquila mountain province for the subsequent seven years. As a reflexive scholar and practitioner, in the days after the earthquake, he began taking notes of his experiences. In his role as a volunteer organiser of community arts events, he developed ideas and plans for actions he could take for social reconstruction within the tent camps. To plan appropriate artistic initiatives, he developed a way of monitoring social conditions in the tent camps. In January 2010, he became involved in a participatory reconstruction project proposal, which enabled him to undertake two years of ethnographic fieldwork in the L'Aquila region, during which time he applied social impact assessment (Benson and Twigg, 2007; Imperiale and Vanclay, 2016b) to enhance the social development outcomes of the project proposal with which he was engaged.

This paper is part of a larger research project looking at the social dimensions of the L'Aquila earthquake at each disaster management phase (Imperiale and Vanclay, 2016a, b; 2019a, b, 2020). The overall project used a wide range of methods, including: action anthropology (Coghlan and Brydon-Miller, 2014); analytic auto-ethnography (Anderson, 2006); participant observation; fieldwork discussions; fieldnotes; blogging; surveys; document analysis; media analysis; a total of 37 in-depth interviews with key informants and over 250 interviews with people in local communities. The data used in this paper primarily come from the participant observation, action anthropology and analytic autoethnography conducted during the reconstruction phase, and from systematic document analysis, media analysis and retrospective in-depth interviewing.

This paper primarily draws on 20 in-depth interviews that specifically focussed on the local community experience of demolition, top-down disaster management and the consequences of this on local governance and community well-being, five done in 2013 and 15 done in 2017. The 2013 interviews were with three local homeowners whose houses had been demolished, and two people who closely knew people whose houses had been demolished. The 2017 interviews were with key local people who were ideal key informants in that they were knowledgeable about what happened in the L'Aquila region after the earthquake and were willing to speak frankly. They were identified by using the lead author's networks and by approaching people mentioned in the media.

The interviews were recorded. Informed consent and general principles of ethical social research were observed (Vanclay et al., 2013). All interviews were done in Italian. For this paper, extracts from some interviews were translated into English by the primary author, with adaptation by the native English speaking co-author. In our translations, we reflected the intended meaning as would be said in English, rather than giving an exact literal 
translation. A draft version of the paper was given to the quoted interviewees for their validation and approval.

\section{The top-down approach to how habitability was assessed and how houses were grouped}

As a result of the earthquake, over 34,000 buildings were damaged to some extent, while some 37,000 buildings had no damage of consequence (DCP, 2018). Less than a month after the earthquake, technical surveys were conducted to evaluate the agibilitá (habitability/liveability) of damaged buildings all over the crater. The criteria for assessing habitability, which were established as a consequence of previous earthquakes, were stated in Ordinance n.3753 of 6 April 2009. Thousands of professionals who came from all over Italy registered as DCP volunteers and together with local professionals were organised and coordinated by the DCP into teams to assess habitability using a DCP habitability form. By October 2009, 73,521 buildings across the crater had been assessed (DCP, 2018), with around 37,000 (52\%) classified "A" (habitable); 11,000 (16\%) classified either "B" or "C" (temporarily uninhabitable); while $23,000(32 \%)$ were classified "E" (uninhabitable) or " $F$ " (adjacent to an $E$ building). Some 1,800 heritage buildings (including 1,045 churches) were assessed separately.

In other post-earthquake interventions in Italy (even those with more damage than L'Aquila), public sector technicians were recruited, first those who were local, then from other regions. Only if more assessors would be needed, would private sector professionals be engaged, and then they were only allowed to support public officers in the assessments. In those cases, the professionals were technically subpoenaed to serve the state and were obligated to observe public duties and procedures. In the L'Aquila situation, however, the DCP made an agreement with the national professional associations so that thousands of freelance professionals could come to the L'Aquila crater. This created problems in relation to the many technicians who did not have the necessary technical competence. An engineer, who had a key role in the design of the habitability assessments, told us:

These professionals were not adequately prepared at all. The technical sheets they had to complete were not overly complicated, but usually required 2-3 days training. In the L'Aquila case, however, freelance professionals were only given instruction for a couple of hours at the DICOMAC offices and then sent to do inspections, often creating confusion. Fortunately, there were also fire service staff who had completed ad-hoc training programs on the methodology of damage assessment and the criteria for compliance with safety standards, and some technicians coming from other regions had completed ad hoc training programs and had obtained the professional qualification of "habitabilitators", but the majority were absolutely not prepared and received only poor training.

The inspections led to initial identification of groupings of houses for planning future reconstruction. These groupings were determined by an automated system the DCP applied to cadastral data. As the engineer explained:

The identification of the groupings of houses ... was made by the DCP in an automated way. The DCP had a set of maps based on cadastral data through which it automatically design groups of houses for proposed reconstruction interventions. However, reality is totally different to cadastral data, which, for example, is not always updated.

Subsequently, private technicians were not required to follow the groupings of houses identified by the DCP. In May 2010, the L'Aquila municipality invited local technicians to submit nominations for new groupings. These nominations had to outline how conducive they were to future reconstruction projects. Thousands of nominations (sometimes overlapping) were submitted and were considered by the municipality. However, there was no requirement for these nominations to have the consent of local homeowners. The overlapping proposals led to conflict between project developers and to confusion among residents. In October 2010, preapproved private technicians were invited to submit preliminary reconstruction project
Failures to build back better in reconstruction 
DPM

29,4

546

proposals. Initially, these proposals were developed only by considering technical matters, such as the structural integrity of the grouping and feasibility of the proposed interventions, without any consent or consultation with the residents.

A crucial issue in post-disaster reconstruction is social and physical proximity. People in different apartments within the same building, or people living in houses that abut others, are examples of proximity. After a disaster, proximity makes it technically impossible for a single homeowner to initiate reconstruction of their house without coordinating with their neighbours. Therefore, in post-disaster reconstruction, a crucial task is not only the identification and establishment of groupings of houses functional to future reconstruction, but, more importantly, the groupings of inhabitants who live in the same neighbourhood (owners' consortia). They need to agree, come to a common vision and undertake collective action for reconstruction.

Governments typically provide state contributions to owners' consortia (not to individual homeowners). Where these consortia do not already exist, states should encourage the establishment of consortia, especially immediately after disasters to enable collective action and the rebuilding of neighbourhood relationships and a sense of community as quickly as possible. In L'Aquila, however, despite complex building structures in which many houses were interlocked, there was no history of owners' consortia. Underlying interests, the topdown procedures implemented and the command-and-control approach meant that there was an institutional ignorance and denial about the desirability of community engagement in the reconstruction process. Nevertheless, continued pressure from inhabitants eventually led to a mayoral ordinance in April 2011, which clarified the procedures by which local homeowners could establish consortia to obtain the state contribution and decide on the planned interventions in relation to their homes and common spaces. The same ordinance also clarified the rights of homeowners. However, in many villages, the formal legal process that ensured respect of local inhabitants' right to participate took many more years before being implemented.

When local inhabitants were finally officially able to decide on the reconstruction of their own homes (after April 2011), they often found it was too late - private building firms (and their technicians) had already been directly appointed by local municipalities and had already undertaken activities on their properties, including: shoring-up solutions, demolitions, identification of groupings of houses for reconstruction and the design of preliminary reconstruction project proposals. The initial reconstruction interventions were techno-driven and business-led, with local people being kept in the dark. There was no procedure to ensure equity and inclusion, which allowed the process to be dominated by people seeking individual gain. As the engineer explained:

[In most cases] the inhabitants delegated everything to the convenors of the owners' consortia, who very often were in cahoots with the technicians and building firms. Thus, the convenors could do whatever they wanted. There were individuals who were the convenor of more than 20 consortia related to the reconstruction of houses. In some rural villages, there was one person who was the convenor of all groups of houses in the village. The local municipality's mistake was that they did not provide proper information to the broader public, and only interacted with local technicians.

\section{Top-down shoring-up and demolition}

Surprisingly, the process of safety measure implementation (i.e. shoring-up solutions and demolitions) was completely separated from the habitability assessments and the identification of groupings of houses for future reconstruction. As the engineer explained:

Safety measure implementation, in theory, should have been designed and implemented according to the habitability surveys that were carried out in the crater. In the habitability form that was designed 
[for rapid habitability assessment], there was much data that could have been immediately used for this purpose. But they didn't even read it! In the habitability form, there was everything: for example, if a building resulted in B "partially habitable", it was also expected that "suggested safety interventions to be implemented" also be completed by the technician. Furthermore, there were some pre-defined standard intervention options, which you simply had to put a cross against. However, this information was not normally used.

Without following the DCP's habitability assessment but only using information coming from inspections that they conducted separately, given the emergency powers they had been granted, the local mayors and their technical managers could directly appoint building firms to demolish buildings or implement shoring-up solutions (Imperiale and Vanclay, 2020). Safety measure implementation and disaster rubble management activities took place over many years, but were heavily concentrated in the first few months. During the three years the state of emergency was in force, these interventions were conducted using no-bid contracts and with derogation of the normal procedures of public procurement, anti-mafia controls, environmental and health safeguard procedures and in the total absence of any public oversight. All this resulted in a lack of strategic programming and no consideration of the longer-term sustainability of the activities conducted, facilitating elite capture, rent-seeking, disaster capitalism, Mafia infiltration and corruption at local and national levels, creating further environmental and social impacts (Imperiale and Vanclay, 2020).

Demolitions were carried out without engaging local homeowners, not with any care regarding materials that could have been reused (e.g. historic stones and planks) or regarding the possessions of inhabitants. This is a breach of decency and dignity and is a violation of the human right to property (Imperiale and Vanclay, 2019a, 2020). In one interview, similar to stories that told by many people, a local homeowner reported that their house was demolished in 2012 without their knowledge or consent, despite being three years after the earthquake:

They did not let me know anything, and only by chance a villager told me that they had demolished my house. I was not called, not even to assist: nothing. That was not fair, was it? What do you think? What if I needed to collect things from home? I did not know anything! I did not see anything. I could not see any draft or project design about the pre-demolition state of my home, or about the demolition procedure they carried out, nothing!

In less than 6 months after the earthquake, the whole red zone of L'Aquila city was "put into safety" (Imperiale and Vanclay, 2020). The red zone was carved-up into districts and assigned to various influential local and national building firms. De Berardinis and De Gregorio (2014) claimed that in L'Aquila city alone, approximately 40,000 cubic metres of wood, 400,000 polyester strap ratchet clamps, 10,000 tonnes of steel, and 2 million segments of tubular scaffolding were used in the temporary safety measures. However, far from putting buildings into safety or being conducive to the effective physical reconstruction of damaged buildings, most safety measures implemented were disproportionate and damaging to property. The attention given to safety measure implementation caused considerable delay to the start of reconstruction, further marginalising and alienating local communities from their properties and their right to decide about their future. It prolonged the collective sense of precariousness, temporariness, uncertainty and lack of a shared vision for the future reconstruction of their city and landscape.

Concerning the enforced temporariness of these safety measures, the engineer (who was also an inhabitant of a mountain village in the crater) stated:

For a clever professional, most safety measures implemented could have immediately been provisional work for the reconstruction of the damaged buildings. For each damaged building, one could have implemented permanent safety measures which would have maintained the building in a safe condition, and enhanced the outcomes from the restoration process. Think about the amount of public money that could have been saved! In my case, fortunately, I already knew the professional of
Failures to build back better in reconstruction 
DPM

29,4

\section{8}

the building firm that was appointed by the L'Aquila Municipality to implement safety measures on my building ... With him, we designed a project in which $60-70 \%$ of the safety materials could be used permanently and left inside the building, thus improving the overall outcomes from restoration. The cost of this material could have been deducted from the total cost of the reconstruction of the building. Thus, just imagine what a saving would have been achieved! However, the technical commission in charge of approving the design of safety measure implementation rejected our proposal because the safety measures were not allowed to be permanent, but had to be temporary! This was crazy! Imagine, on the contrary, how much money could have been saved if there was a different way of thinking about this!

Although safety measure implementation did not function as provisional works for the future reconstruction of damaged buildings, for the building firms they acted as a sort of preemptive option over buildings in relation to likely future reconstruction work. Removing the safety measures was complicated, and many homeowners considered it would be quicker to appoint the same building firm that installed the safety measures to do the reconstruction work. Furthermore, by having already worked on their buildings, the building firms could easily contact the inhabitants and they used these arguments as leverage to get appointed to do the permanent reconstruction. As the engineer confirmed:

In most cases, the private building firms appointed for the implementation of the shoring-up solutions were the same as those that became appointed for the reconstruction project and works.... In my case, however, I kicked the private building firm that implemented the shoring-up solution out from my house after he completed the preliminary work. I told him: I even know you, sorry, but I will let another building firm, one I want, to do the work on the proper reconstruction design and implementation of my house and the group of houses in which my house has been included.

Safety measure implementation was not accompanied by any mid or long-term planning, or by any consideration of the social-ecological lifecycle of the materials being used, nor of how these interventions could have contributed to the physical reconstruction of the buildings (De Berardinis and De Gregorio, 2014). At the time of writing (early 2020), effective and sustainable procedures for dismantling, transporting, storing and re-using (or disposing) the safety measures are still unclear. The process of dismantling them and finding adequate arrangements for their storage and reuse is complicated. As the engineer explained:

When the proper physical reconstruction of the buildings began, because of their temporariness, the safety bracings had to be removed ... We proposed that the safety bracings should have been left in the hands of the building firm . . . as removing them is not an easy task, especially after 7-8 years. Leaving these materials to the building firms, ... so they could reuse them or sell them back to the market, would have ... [reduced] further bureaucracy. But, no, the local municipality invented a system in which someone had to remove them, weigh them, and deliver them to the municipality. I told the municipality that, if we do this, we risk sending many people to jail because, if one is meticulous in this procedure, it would reveal that, based on the original cost estimate, the building firm had claimed 100 joints at $€ 28$ each - when actually they cost $€ 6$, and that this was another big source of profit. Then, when one dismantles them, and instead of 100, they find only 60 joints, what should one do? Should one have to denounce the building firm? Should one have to send the building firm and the local municipality [who approved this implementation] to jail? [laughs] It is pointless to deal with this shit. Let's do a rough compensation and that's it. But instead, one has to dismantle them, weigh them, and bring them to the municipality. However, the municipality does not have sufficient space to store these things, so the building firms have to bear a double cost, also the cost of renting space to store them until the municipality can take them back. ... The incredible cost of the temporary measures implemented this way was thus doubled: the state first paid to implement them; now they are paying to remove them. Meanwhile, the delay to physical reconstruction is unbearable.

The total cost of the shoring-up solutions and demolitions implemented by private firms appointed by direct assignment by local municipalities was over $€ 628$ million (GSSI, 2018). 
The costs were managed by the directors of the municipal technical offices and local mayors, using the Civil Protection Fund. There was no public disclosure or monitoring of these actions, which were covered by state secrecy provisions. The local municipalities were not required to produce any official financial statement (Imperiale and Vanclay, 2020).

The safety measures delayed the proper reconstruction process and prolonged the collective sense of precariousness, temporariness, uncertainty and lack of a shared vision for the future reconstruction. After 10 years, all town centres of the crater still have red zones, to which access is still formally restricted. An inhabitant of a mountain village (interviewed in 2017) told us:

Safety measures perhaps should be implemented immediately after the disaster, but they should not remain after almost ten years ... My village is a red zone, substantially it is still a red zone! ... I remember, after 5 years, I was going to my house, which is in the red zone, and some personnel in uniform, probably from the DCP, who just happened to be there, stopped me, looked at me and asked: Where are you going? I know that these people were acting in a good faith, but you come and say to me "Where are you going?" To me? In my village? ... thus, "Please, get out of my place!" Can't I go to my home, or do I have to call the Fire Service to go to my home? After 5 years! Really? I might accept this after one or two months, or even after six months! But you, after 5 years, come to me and ask me, Where are you going? I asked them "where they were going" [laughs] and "where did they come from" [laughs]!. . . Now, after almost 10 years, access to our village is still formally denied and this is totally unacceptable.

\section{Top-down reconstruction policy, design and implementation}

In L'Aquila, the habitability assessments were used for different purposes than in previous post-disaster situations, such as the Umbria (1997) and Molise (2002) earthquakes. Rather than providing general information that could have supported a coherent assessment of the public need for temporary housing, the amount of public money needed for reconstruction, or the design of a coherent reconstruction policy, the primary purpose of the quick habitability assessment was to support requests by individuals for a state contribution to reconstruction of their dwelling.

One issue of concern was that the government ordinances that enabled the state contribution (OPCM n.3779 on 6 June 2009 and OPCM n.3790 on 7 July 2009) were issued while the habitability assessments were still being conducted. This meant that the technicians doing the assessments realised that there would be little scrutiny of their assessments, and that they were in a prime position to exaggerate the damage, inflate the estimated cost of reconstruction and subsequently benefit from future reconstruction works. The engineer we interviewed stated:

Issuing these ordinances while the habitability assessment was still going on allowed assessments to be distorted by private interests, so that many technicians made the habitability results worse than they were in reality. Another contradiction created was that the habitability assessment results say little about the damage to each building produced by the earthquake itself that the state contribution was intended to address. Many buildings could get a habitability assessment of " $E$ ", not "habitable", yet have little damage that was directly due to the earthquake. This resulted from the fact that a nonhabitability rating "E" could be given by noting that the building was not accessible because there were unstable buildings nearby, or there were unstable buildings threatening it. Even if there was only a precarious chimney that threatened the main entrance of a building, this would render the building as "not habitable" [even if it was in otherwise fine condition]. In one study ... it was determined that across the whole crater, $10 \%$ of buildings declared E actually had little damage or no damage at all. Even if they had only little damage, they were considered the same as "not habitable" so that they could get the maximum amount of money possible from the state contribution. 
DPM

29,4

\section{0}

The engineer further explained:

In the case of the Umbria and Marche earthquakes in 1997 and in the case of the Molise earthquake in 2002 , the state contribution [to owners] was strictly tied to the assessment of damage created by the earthquake, the dimensions of the damaged building and to its structural vulnerability, up to a defined maximum amount that could be claimed from the state. However, in the case of L'Aquila, before the introduction of a new survey form [scheda parametrica], which was issued in 2012, there was no established maximum that could be requested. The state contribution was not tied to any damage assessment but could only be approved according to the habitability results and the amount of money that was estimated by the private reconstruction project. Only when the new survey sheet was introduced in 2012 could we require that the state contribution had to be directly proportional to the damages created by the earthquake and to the intrinsic vulnerability of the building itself, up to an established maximum.

Before the scheda parametrica was introduced, there was massive proliferation of reconstruction projects and much inflation in the proposed cost of projects, many of which were approved and funded by the state. As the engineer explained (slightly modified for clarity):

Another nonsense was that, before the introduction of the scheda parametrica, for a building with 10 apartments you had to present 11 projects: 1 project for each apartment and 1 project for the common parts. This was an absurd thing, technically speaking. It brought ... a proliferation in the number of assignments for reconstruction projects. The splintering of the whole building into different subprojects for each single apartment within the same building increased the cost of the projects. This was especially because the discretionary overhead (mark-up) of a project is inversely proportional to the cost of the whole project: to simplify with an example, for a reconstruction of 50,000 euros, the mark-up is $15 \%$, whereas on a reconstruction of 300,000 euros, the mark-up is 7\%. [so if you chop a project up into little pieces, the total cost is increased, and the more money the technicians get].

Another controversial issue is related to how public funds for heritage reconstruction were managed. A separate procedure to access the state contribution for the reconstruction of buildings designated as heritage was established, with approval of requests being conducted by the local heritage authority. This was quicker than the normal procedure. The owners of heritage buildings also benefitted from an additional allowance equivalent to the reconstruction cost estimate made by the reconstruction project (in other words, they received double the amount) (OPCM n.3917, 2010, Article 21, subpara.2). The rationale for this double payment ostensibly was that heritage building owners were expected to use the extra funds to conduct additional works to ensure greater seismic resistance in the future. However, there was no requirement that the heritage status had to have been determined prior to the earthquake, and consequently there was distortion in claims under this mechanism. After the earthquake, some people were able to get their building declared heritage so they could benefit from the quicker process and extra payment. As our engineer informant explained:

Buildings considered heritage could get access to an amount of money that was double what ordinary buildings could get. This was totally wrong, simply because of the fact that many buildings could be considered heritage only because a small portion of them was old, or because they had one window frame from the 14th century. However, no matter how little the detail was, ... the building would be considered heritage in its totality, and could get double the State contribution for reconstruction. Only after the scheda parametrica was implemented could we introduce a criterion that the State contribution had to be directly proportional to the heritage elements.

\section{The failure to build back better more resilient communities}

To build back better more resilient communities, any planned intervention should engage and empower local communities and build a community culture of well-being, DRR and 
resilience that enhances inclusive social learning and socially-sustainable transformation. To develop such a community culture, knowledge about community well-being, vulnerabilities, risks and impacts must be co-produced with affected local communities and be transformative (Jerneck et al., 2011; Imperiale and Vanclay, 2016b). Advances in disaster studies emphasise the need for social impact assessment to accompany disaster management and development interventions, including post-disaster reconstruction (Benson and Twigg, 2007; Jha et al., 2010; UNISDR, 2015; Finucane et al., 2020). Recent application of social impact assessment has expanded from its traditional domain to now co-producing transformative knowledge with affected local communities and to influencing the conception, decision, design and implementation of planned interventions to enhance social learning and transformation, DRR and community well-being and resilience (Imperiale and Vanclay, 2016b; Kruger et al., 2020; Finucane et al., 2020; Vanclay, 2020).

Such co-produced and transformative knowledge should be embodied in each component of planned interventions (i.e. the institutional strategy, financial strategy, physical planning and community participation) and must encourage empathy, caring, social responsibility and strengthen cooperation and mutual aid. These positive feelings, attitudes and behaviours enable local people to: collectively understand disaster risks and impacts; recognise local vulnerabilities to reduce and identify the vulnerable members of their community to support; and to enhance local knowledge, capacities and assets to co-design and co-develop, together with the disaster management and development agencies, mitigation strategies to enhance DRR, community well-being and resilience. This co-produced and transformative approach enhances sense of risk, sense of place and sense of community, all of which are crucial for building community resilience, and such an approach should inform each of the five components orienting planned intervention from before conception to after completion (Berkes and Ross, 2013, 2016; Imperiale and Vanclay, 2016a, b).

As revealed here and in our previous work (Imperiale and Vanclay, 2020), however, the institutional strategy enacted by the Italian state, at least up to 2012, was to provide emergency powers which enabled interventions to be carried out with derogation of the public procurement, anti-mafia controls, public health and environmental safeguard procedures normally required (e.g. environmental impact assessment, risk monitoring, environmental safety measures, protection of groundwater at waste disposal sites, etc.) (Imperiale and Vanclay, 2020). The institutional strategy was to regulate the reconstruction process and the state contribution via a large number of ordinances and decrees. Changes in these arrangements created differences in treatment, confusion and alienation of most people, especially the most vulnerable. Derogations transformed rubble, safety measure implementation, demolitions and reconstruction interventions into avenues for elite capture, corruption, disaster capitalism and organised crime infiltration (Postiglione, 2010; DNA, 2017; Bindi, 2018; Imperiale and Vanclay, 2020).

During the 3 years of the state of emergency, the DCP and local authority figures adopted a top-down, command-and-control approach to allocate financial resources for post-disaster interventions. Funding was made available by the state through the Civil Protection Fund and other financial arrangements. Under the emergency powers and covered by state secrecy provisions, the national and local authority figures had access to unlimited funds. Local authority figures used no-bid contracts to appoint building firms to demolish buildings, design and implement shoring-up solutions, manage disaster rubble, implement infrastructure and reconstruct public buildings, including schools, churches and other heritage properties. All activities lacked transparency and accountability, something that undermined inclusive and participatory social learning and transformation. The state secrecy provisions, lack of disclosure and derogations associated with the state of emergency, served to hide dubious arrangements, disguise fraud and corruption and facilitated disaster capitalism and organised crime infiltration, thus worsening inequity, social exclusion and
Failures to build back better in reconstruction 
DPM

29,4

552

exacerbating vulnerability and associated disaster risks and impacts (Imperiale and Vanclay, 2019a, 2020).

The procedures used by the state did not require any engagement of local communities or their elected councils during conception, decision, design or implementation of post-disaster interventions. The command-and-control approach meant that local political leaders gained autocratic powers, while the local elected councils and local communities were excluded from decision making. No participatory community needs assessment was done. Local people's ideas about possible alternative solutions were not taken into consideration. Similarly, in the actions implemented by local authority figures, only the Directors of the technical offices, DICOMAC and state-owned companies were consulted, at the expense of the local democratic governance of the crater, further marginalising local communities from the reconstruction of their own future (Imperiale and Vanclay, 2019a, 2020).

Before and after the L'Aquila earthquake, the mitigation of vulnerabilities, risks and impacts was considered to be only the responsibility of national and local authority figures. The knowledge that used to inform initial reconstruction interventions was deemed to be only techno-scientific knowledge relating to the vulnerabilities of the built environment, rather than being co-produced, transformative and related to the multiple dimensions of community well-being and resilience. There was no requirement to consider how to preserve and strengthen neighbourhood relationships, or reduce the environmental, social and human rights risks and impacts that disaster management and development interventions created at the local level. Nor was there any requirement to ensure the mid to long-term sustainability of these interventions, or prevent exacerbation of local social risks, vulnerabilities and the root causes of disaster.

The only social risks considered were looting and other behaviours considered deviant by the authorities (e.g. anxiety, alarmism and unsafe actions), so that, instead of being a matter of community well-being and resilience, risk management became a matter of public control, which, before disasters led to police action, and after disasters led to militarisation of the affected area (Imperiale and Vanclay, 2019a, b, 2020). All this further exacerbated the exclusion and marginalisation of local inhabitants from the reconstruction of their homes and neighbourhoods. There was nothing in the system to assess and avoid the risks of rentseeking, elite capture, weak local governance, disaster capitalism or organised crime infiltration (Imperiale and Vanclay, 2019a, 2020).

\section{Conclusion}

The L'Aquila disaster is not just an Italian story of corruption and organised crime infiltration, but it reveals much more. Within local communities, there can be resilience as well as counter-productive actions, such as elite capture, rent-seeking, infiltration of organised crime, disaster capitalism and corruption. The way disaster management and development interventions are conceived, decided, designed and implemented can facilitate both negative and positive trends in local communities. Beyond being the result of endemic vulnerabilities and social risks, disasters are also the product of the top-down planning approach, which produces structural failures at all levels of society, including counterproductive learning and counterproductive transformation.

Consistent with the paradigm shift around the world, from a war approach to considering disasters in the context of socially-produced vulnerability (i.e. the DRR and resilience paradigm), there has been a change from civil defence to civil protection (Alexander, 2002). Unfortunately, as is evident from our research, this change has not been accompanied by any change in the traditional military-type, top-down, command-and-control approach, or in the institutional arrangements or management models, thus, continually reproducing structural failures. 
We argue that, in order to avoid such structural failures, the switch from the war approach to considering disasters in the context of socially-produced phenomena requires much more than switching from civil defence to civil protection systems. To build back better resilient communities, the mechanism enacted by states that adopt centralised civil protection systems must be abolished. A crucial shift in disaster management and development thinking and practice from protecting vulnerable, affected communities to empowering their capacities to learn and transform, and from top-down, centralised civil protection systems to decentralised, socially-sustainable community empowerment systems, is needed. Such decentralised community empowerment systems must orient each of the five components of disaster management and development interventions and enable inclusive social learning and socially-sustainable transformation towards reducing local vulnerabilities, risks and impacts and the root causes of disasters, enhancing DRR and resilience at all levels of society. These decentralised, socially-sustainable community empowerment systems should put at the core of any planned intervention community health and well-being and should contribute to building a community culture of resilience, rather than of disaster capitalism. Such a shift would help external actors and local communities turn affected landscapes into landscapes of affect, rather than carcasses to exploit.

\section{References}

Adger, W.N. (2000), "Social and ecological resilience: are they related?", Progress in Human Geography, Vol. 24 No. 3, pp. 347-364.

Alexander, D. (2002), "From civil defence to civil protection - and back again", Disaster Prevention and Management, Vol. 11 No. 3, pp. 209-213.

Amin, S. and Goldestein, M. (2008), Data against Natural Disasters: Establishing Effective Systems for Relief, Recovery and Reconstruction, World Bank, Washington.

Anderson, L. (2006), "Analytic autoethnography", Journal of Contemporary Ethnography, Vol. 35 No. 4, pp. 373-395.

Benson, C. and Twigg, J. (2007), Tools for Mainstreaming Disaster Risk Reduction: Guidance Notes for Development Organisations, Provention Consortium, Geneva.

Berkes, F. and Ross, H. (2013), "Community resilience: toward an integrated approach”, Society and Natural Resources, Vol. 26 No. 1, pp. 5-20.

Berkes, F. and Ross, H. (2016), "Panarchy and community resilience: sustainability science and policy implications", Environmental Science and Policy, Vol. 61, pp. 185-193.

Berkes, F., Colding, J. and Folke, C. (2003), Navigating Social-Ecological Systems: Building Resilience for Complexity and Change, Cambridge University Press, Cambridge.

Bindi, R. (2018), "Commissione Parlamentare di Inchiesta sul fenomeno delle mafie e altre organizzazioni criminali, anche straniere", Relazione conclusive, (Draft) available at: http://www.avvisopubblico.it/ home/wp-content/uploads/2018/02/XXIII-n.-38.pdf (accessed 22 March 2020).

Chang, Y., Wilkinson, S., Seville, E. and Potangaroa, R. (2010), "Resourcing for a resilient post-disaster reconstruction environment", International Journal of Disaster Resilience in the Built Environment, Vol. 1 No. 1, pp. 65-83.

Coghlan, D. and Brydon-Miller, M. (Eds) (2014), The Sage Encyclopedia of Action Research, Sage, Thousand Oaks.

Davidson, D. (2010), "The applicability of the concept of resilience to social systems: some sources of optimism and nagging doubts", Society and Natural Resources, Vol. 23 No. 12, pp. 1135-1149.

De Berardinis, P. and De Gregorio, S. (2014), "Temporary systems after the earthquake in L'Aquila", Mobile and Rapidly Assembled Structures, Vol. IV No. 136, p. 47.

DNA (Direzione Nazionale Antimafia e Antiterrorismo) (2017), "Relazione annuale sulle attività svolte dal Procuratore Nazionale e dalla Direzione Nazionale antimafia e antiterrorism", available at:
Failures to

build back better in reconstruction 
DPM

29,4

http://www.avvisopubblico.it/home/wp-content/uploads/2017/06/RELAZIONE-DNA-1.7.201530.6.2016.pdf (accessed 22 March 2020).

Ellerman, D. (2006), Helping People Help Themselves. From the World Bank to an Alternative Philosophy of Development Assistance, University of Michigan Press, Ann Arbor.

Finucane, M.L., Acosta, J., Wicker, A. and Whipkey, K. (2020), "Short-term solutions to a long-term challenge: rethinking disaster recovery planning to reduce vulnerabilities and inequities", International Journal of Environmental Research and Public Health, Vol. 17 No. 2, p. 482.

Folke, C., Carpenter, S., Walker, B., Scheffer, M., Chapin, T. and Rockström, J. (2010), "Resilience thinking: integrating resilience, adaptability and transformability", Ecology and Society, Vol. 15 No. 4, p. 20.

Folke, C. (2006), "Resilience: the emergence of a perspective for social-ecological systems analyses", Global Environmental Change, Vol. 16, pp. 253-267.

Galullo, R. (2009), "Abruzzo/ Le fissure nel muro che le mafie possono far diventare un nuovo terremoto: bandi di gara, corruzione e Massimo ribasso", in Il Sole 24 Ore, online, 17 April, 2009, available at: http://robertogalullo.blog.ilsole24ore.com/2009/04/17/abruzzo-le-fessure-nel-muroche-le-mafie-possono-far-diventare-un-nuovo-terremoto-bandi-di-gara-corruzione-e-massimoribas/?refresh_ce=1 (accessed 22 March 2020).

GSSI (2018), "Ricostruzione privata, open data ricostruzione", 28 February, 2018, available at: opendataricostruzione.gssi.it/ricostruzione-privata/ (accessed 22 March 2020).

IDNDR (1994), "Yokohama strategy and plan of action for a safer world: guidelines for natural disaster prevention, preparedness and mitigation", available at: http://www.ifrc.org/Docs/idrl/ I248EN.pdf (accessed 22 March 2020).

Illich, I. (1976), Medical Nemesis: The Expropriation of Health. Pantheon Books, New York.

Illich, I. (1978), Toward a History of Needs, Pantheon Books, New York.

Imperiale, A.J. and Vanclay, F. (2016a), "Experiencing local community resilience in action: learning from post-disaster communities", Journal of Rural Studies, Vol. 47, pp. 204-219.

Imperiale, A.J. and Vanclay, F. (2016b), "Using social impact assessment to strengthen community resilience in sustainable rural development in mountain areas", Mountain Research and Development, Vol. 36 No. 4, pp. 431-442.

Imperiale, A.J. and Vanclay, F. (2019a), "Command-and-control, emergency powers, and the failure to observe United Nations disaster management principles following the 2009 L'Aquila earthquake", International Journal of Disaster Risk Reduction, Vol. 36, p. 101099.

Imperiale, A.J. and Vanclay, F. (2019b), "Reflections on the L'Aquila trial and the social dimensions of disaster risk", Disaster Prevention and Management, Vol. 28 No. 4, pp. 434-445.

Imperiale, A.J. and Vanclay, F. (2020), "The mechanism of disaster capitalism and the failure to build community resilience in post-disaster situations: learning from the L'Aquila earthquake", Disasters, doi: 10.1111/disa.12431.

Jerneck, A., Olsson, L., Ness, B., Anderberg, S., Baier, M., Clark, E., Hickler, T., Hornborg, A., Kronsell, A., Lövbrand, E. and Persson, J. (2011), "Structuring sustainability science", Sustainability Science, Vol. 6 No. 1, pp. 69-82.

Jha, A.K., Barenstein, J., Duyne, P., Priscilla, M., Pittet, D. and Sena, S. (2010), Safer Homes, Stronger Communities: A Handbook for Reconstructing after Natural Disasters, World Bank, Washington DC, available at: https://openknowledge.worldbank.org/handle/10986/2409 (accessed 22 March 2020).

Khakee, A. (2009), A Comparative Analysis of Emergency Powers in Europe, Geneva Centre for the Democratic Control of Armed Forces, Geneva, available at: https:/www.files.ethz.ch/isn/99550/ pp30_anna_khakee_emergency_powers.pdf (accessed 22 March 2020).

Kruger, L., Sandham, L.A. and Van Niekerk, D. (2020), "Improved SIA through DRA integration: lessons from a South African legislative comparison”, Impact Assessment and Project Appraisal, Vol. 38 No. 1, pp. 71-82. 
Libera (2010), "Dossier Abruzzo. Crepe 6 Aprile 2009 ore 3.32. La fine dell'isola felice, in Site.it”, available at: http://www.site.it/le_testate/_notes/DOSSIER\%20LIBERA\%20web.pdf (accessed 22 March 2020).

Norris, F., Stevens, S., Pfefferbaum, B., Wyche, K. and Pfefferbaum, R. (2008), "Community resilience as a metaphor, theory, set of capacities and strategy for disaster readiness", American Journal of Community Psychology, Vol. 41, pp. 127-150.

Oliver-Smith, A., Alcántara-Ayala, I., Burton, I. and Lavell, A. (2017), "The social construction of disaster risk: seeking root causes", International Journal of Disaster Risk Reduction, Vol. 22, pp. 469-474.

Postiglione, A. (2010) "Affari e terremoti: svelate le trame che hanno ricostruito l'Abruzzo", Verso L'Aquila, 13 March, 2010, available at: https://versolaquila.wordpress.com/2010/03/13/svelatele-trame-che-hanno-ricostruito-1\%E2\% 80\%99abruzzo/ (accessed 22 March 2020).

Quarantelli, E.L. ed. (1998), "What is a Disaster?", A Dozen Perspectives on the Question, Routledge, London.

Sadiqi, Z., Trigunarsyah, B. and Coffey, V. (2017), "A framework for community participation in postdisaster housing reconstruction projects: a case of Afghanistan”, International Journal of Project Management, Vol. 35 No. 5, pp. 900-912.

Søndergaard, S. (2013), "Feedback report on the fact-finding mission to Italy, 2013", available at: http:// www.europarl.europa.eu/meetdocs/2009_2014/documents/cont/dt/1007/1007699/1007699en.pdf (accessed 22 March 2020).

UNDRO (1982), Shelter after Disaster: Guidelines for Assistance, Office of the United Nations Disaster Relief Co-Ordinator, Geneva, available at: https://reliefweb.int/report/world/shelter-afterdisaster-guidelines-assistance (accessed 22 March 2020).

UNISDR and UNDP (2007), "Building disaster resilient communities: good practices and lessons learned, United Nations international strategy for disaster reduction", Geneva, available at: https://www.unisdr.org/files/596_10307.pdf (accessed 22 March 2020).

UNISDR (2005), "Hyogo framework for action 2005-2015: building the resilience of Nations and communities to disasters", available at: http:/www.unisdr.org/2005/wcdr/intergover/officialdoc/L-docs/Hyogo-framework-for-action-english.pdf (accessed 22 March 2020).

UNISDR (2007), Building Disaster Resilient Communities: Good Practices and Lessons Learned, United Nations Development Program, Geneva, available at: http://www.unisdr.org/files/596_10307.pdf (accessed 22 March 2020).

UNISDR (2015), "Sendai framework for disaster risk reduction 2015-2030", available at: http://www. preventionweb.net/files/43291_sendaiframeworkfordrren.pdf (accessed 22 March 2020).

Vanclay, F., Baines, J. and Taylor, C.N. (2013), "Principles for ethical research involving humans: ethical professional practice in impact assessment Part I", Impact Assessment and Project Appraisal, Vol. 31 No. 4, pp. 243-253.

Vanclay, F. (2020), "Reflections on social impact assessment in the $21^{\text {st }}$ century", Impact Assessment and Project Appraisal, Vol. 38 No. 2, pp. 126-131.

Venice Commission (1995), "Emergency powers, Strasburg: European commission for democracy through law", available at: http://www.venice.coe.int/webforms/documents/default.aspx? pdffile $=$ CDL-STD(1995)012-e (accessed 22 March 2020).

\section{Corresponding author}

Angelo Jonas Imperiale can be contacted at: a.j.imperiale@rug.nl

For instructions on how to order reprints of this article, please visit our website:

www.emeraldgrouppublishing.com/licensing/reprints.htm

Or contact us for further details: permissions@emeraldinsight.com 